\title{
BADANIA MODALNE PĘKNIĘĆ BLOCZKÓW BETONOWYCH
}

\author{
Mariusz Żółtowski ${ }^{\boxplus}$, Norbert Dąbkowski \\ ${ }^{1}$ Centrum Wodne \\ 2 Instytut Inżynierii Lądowej \\ Szkoła Główna Gospodarstwa Wiejskiego w Warszawie
}

\begin{abstract}
STRESZCZENIE
W przedstawionym opracowaniu wskazano na możliwość wykorzystania złożonych estymatorów rozpływu energii drganiowej wykorzystywanych w badaniu jakości bloczków betonowych w ramach opracowanej do tego celu metodologii badań drganiowych. Analizy teoretyczne i weryfikacja praktyczna badania wrażliwości informacyjnej miar złożonych procesów drganiowych wskazują na szerokie możliwości ich zastosowania. W celu doskonalenia metod badań uszkodzeń materiałów betonowych dla potrzeb oceny ich stanu degradacji, w tej pracy przedstawiono istotne wyniki postępowania badawczego w zakresie weryfikacji skuteczności proponowanych miar wzajemnych w badaniach stanowiskowych bloczków betonowych.
\end{abstract}

Słowa kluczowe: obciążenia konstrukcji, degradacja stanu, drgania, estymatory drganiowe, opracowanie statystyczne

\section{WSTĘP}

Identyfikacja w konstrukcjach budowlanych staje się metodą oceny zmian stanu eksploatacyjnego konstrukcji, a metody analizy modalnej i związanych $z$ nią estymatorów drganiowych dobrze odzwierciedlają destrukcję elementów betonowych. Poszukiwanie odwzorowań stanu materiału budowlanego z parametrami ich modeli drganiowych (w badaniach stanowiskowych i na rzeczywistych obiektach) pozwoliło dokonać oceny podobieństwa modeli, trafności decyzji i skuteczności stosowanej metody badań. Ocena stanu dynamicznego materiałów budowlanych za pomocą miar propagacji energii drganiowej wymaga skojarzenia cech struktury ocenianego obiektu ze zbiorem miar i ocen procesów wyjściowych (Brandt, 1999; Peeters i Ventura, 2003).

Pomiary drgań wraz z ich interpretacją fizyczną (zaproponowany model przejścia sygnału drganiowego przez materiał) stanowią bazę pozyskiwania informacji w badaniu destrukcji wybranych elementów murowych.
Badania podstawowe $\mathrm{w}$ tej pracy prowadzone dla potwierdzenia założeń i warunków specyficznych badań destrukcji weryfikują słuszność przyjętych modeli, a zarejestrowane sygnały drganiowe pozwalają scharakteryzować właściwości dynamiczne badanych materiałów. Elementy teorii modelowania i badań symulacyjnych (niezbędne wręcz w rozpoznaniu właściwości badanych elementów) pozwalają stwierdzić, czy dowolny obiekt badań (materiał budowlany) w największym uproszczeniu modelowany za pomocą parametrów $m, k, c$-układem o jednym stopniu swobody - można traktować jako sztywny układ liniowy (Natke i Cempel, 1997).

Rozważania tej pracy wskazują, że własności tak zamodelowanych elementów obiektów można analizować poprzez ich opis równaniami różniczkowymi (rozwiązując zagadnienie własne) lub te same informacje można uzyskać, dokonując pomiaru drgań $(a, v, x$ - parametry procesu drganiowego) i na ich podstawie przeprowadzając procedurę wyznaczania drganiowych miar wzajemnych (Uhl, 1997; Batel, 2002; Pickrel, 2002). 
Omówione definicyjnie i od strony praktycznych zastosowań miary procesu drganiowego (z uwagi na proces uśredniania podczas ich wyznaczania nazywane estymatorami) wskazują na duży zakres czynności, niezbędnych podczas akwizycji i przetwarzania informacji, czynności programowanych w czasie komputerowego opracowywania i prezentacji danych pomiarowych.

\section{DRGANIA W DEGRADACJI BLOCZKÓW BETONOWYCH}

Przy badaniach rzeczywistych układów (konstrukcje, budowle, maszyny, urządzenia) podstawowym problemem jest określenie wartości energii wibroakustycznej magazynowanej, rozpraszanej i przenoszonej przez poszczególne elementy tych układów. Znajomość tych wielkości służy ocenie wytężenia materiału, zmęczenia, badań diagnostycznych oraz predykcji hałasów, a także ułatwia projektowanie elementów układu (Richardson i Formenti, 1982).

Na rysunku 1 przedstawiono podstawowe (przykładowe) przebiegi zmian mierzonej amplitudy w czasie dla kolejnych pomiarów, które są podstawą dalszych opracowań programowych dla potrzeb wyróżnienia informacji o zmianach stanów.

a

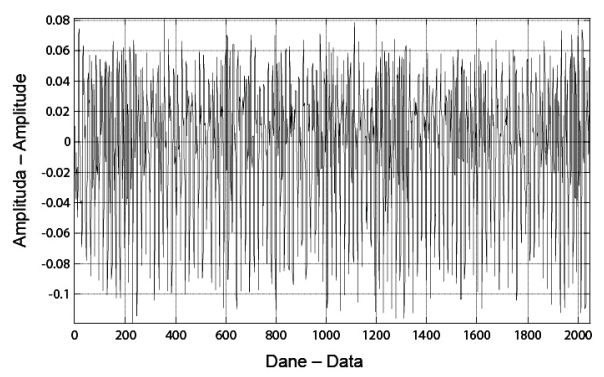

Podstawowy wynik pomiaru przebiegu czasowego i jego analiza widmowa pokazane zostały na rysunku 2. Są to główne rodzaje przekształceń sygnału stosowane w dalszej części tej pracy, gdyż wszystkie inne charakterystyki sygnału drganiowego opierają się na powyższych przebiegach.

Procesy drganiowe to $\mathrm{w}$ większości przypadkowe procesy, dlatego dalej są przetwarzane $\mathrm{w}$ procesorze według różnych algorytmów dla otrzymania różnego typu estymatorów sygnałów. Estymatory te w odróżnieniu od sygnałów są zdeterminowane i w zależności od swojego rodzaju odzwierciedlają różne cechy i własności informacyjne sygnałów (Richardson, 1997; Żółtowski, 2005).

Estymatory jako miary liczbowe procesu drganiowego są definiowane w trzech kategoriach opisu sygnału: czasu, częstotliwości i amplitud (Bischoff, Wall, Bletzinger i Ramm, 2004) i jako wielkości zdeterminowane oddające stan ocenianego materiału mogą być porównywane ze wzorcami stanu badanych materiałów.

W dostępnej literaturze (Żółtowski, 2007, 2011a, 2014) przedstawiono definicje i właściwości różnych estymatorów drganiowych, wyróżniając estymatory własne (dotyczace jednego sygnału) i estymatory wzajemne (dotyczące dwóch sygnałów).

b

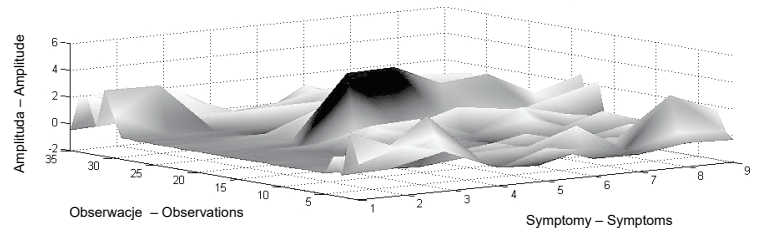

Rys. 1. Pomiary zmian amplitudy w czasie dla kolejnych pomiarów drgań

Fig. 1. Measurements of amplitude changes over time for successive vibration measurements

a

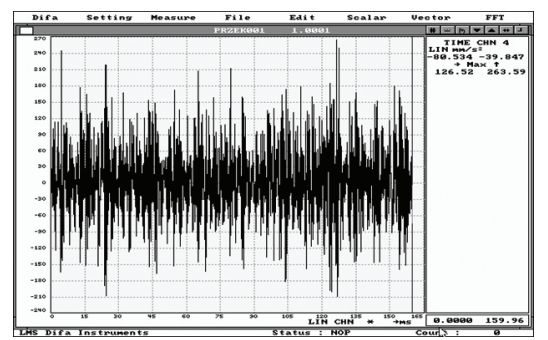

b

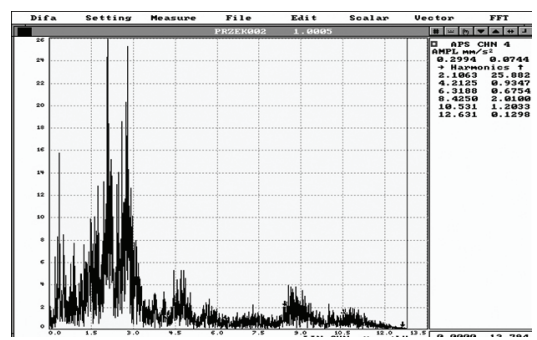

Rys. 2. Przebieg czasowy (a) i widmo sygnału drganiowego (b)

Fig. 2. Time course (a) and the spectrum of the vibration signal (b) 
Nowe narzędzia w tym obszarze badań dotyczą możliwości wykorzystania metodyki badania rozpływu energii drganiowej, a także nowoczesnego pozyskiwania i przetwarzania miar drganiowych - do oceny jakości elementów murowych, które stanowią podstawę rozważań w tej pracy. W praktycznych zastosowaniach pozwalają one na lepsze zrozumienie zachowania się złożonych konstrukcji, optymalizację w procesie ich projektowania i ocenę stanów niebezpiecznych. W tym ostatnim obszarze lokują się treści podejmowanej tematyki, poszukujące miar oceny stanu destrukcji elementów murowych nowych, wieloletnich i często o nieznanym stanie destrukcji i współczynniku bezpieczeństwa muru wielu budowli (Bishop i Johnson, 1980).

Metodyka badania rozpływu energii drganiowej zastosowana w rozważaniach tej pracy została zaadoptowana $\mathrm{z}$ obszaru dynamiki konstrukcji mechanicznych. Jej przydatność jest większa dla jednorodnych struktur konstrukcji stalowych niż dla materiałów budowlanych takich jak elementy murowe, w kórych przypadku każdy wynik badania jest związany ze strukturą, z kształtem i ze stanem fizycznym próbki. Jest więc obawa, że niejednorodność i gruboziarnista struktura betonu i ceramiki mogą być przeszkodą co do skuteczności bardzo precyzyjnych technik pomiarowych. Zadaniem tej pracy jest więc ocena przydatności miar rozpływu energii drganiowej w diagnozowaniu jednorodnych elementów murowych (cegły, bloczków, pustaków) oraz wypracowanie zaleceń do badania bardziej niejednorodnych fragmentów murowych (Vold, Kundrat, Rocklin i Russell, 2010).

Zadania tej pracy obejmują szczegółowo zagadnienia: modelowania i opisu procesu destrukcji elementów murowych, wykorzystania drgań w opisie zmian ich stanu dynamicznego, realizacji badań niszczących elementów i segmentów murowych, zastosowania systemu oprogramowania do pozyskiwania i przetwarzania danych pomiarowych.

Uzyskane wyniki zrealizowanej pracy wskazują na miary drganiowe charakteryzujące destrukcję badanych elementów murowych, wyznaczonych metodą eksperymentu stanowiskowego opartego na pomiarach i przetwarzaniu sygnału drganiowego. Oceniają także modele destrukcji bloczków betonowych oraz tworzą podstawy budowy prostych procedur diagnostycznych dla potrzeb systemu kontroli wyrobów budowlanych wprowadzanych do obrotu.
Do miar tych należą (Brunarski, 1996):

- transmitancja: dynamikę układu w dziedzinie częstotliwości można opisać za pomocą równania:

$$
X(j \omega)=H(j \omega) F(j \omega)
$$

gdzie:

$X(j \omega)$ - wektor widm odpowiedzi układu,

$H(j \omega)$ - macierz charakterystyk częstotliwościowych,

$F(j \omega)$ - wektor widm sił wymuszających;

- widmowa funkcja przejścia (ang. frequency response function - FRF) będąca funkcją częstotliwości opisującą relacje między siłą wymuszenia $F(t)$ a przyspieszeniem drgań $a(t)$ jako sygnałem odpowiedzi; można ją opisać jako iloraz wartości transformaty Fouriera siły wymuszającej drgania $F(\omega)$ przez transformatę Fouriera sygnału odpowiedzi $A(\omega)$ :

$$
F R F=\frac{\sum F(\omega)}{\sum A(\omega)}
$$

Widmowa funkcja przejścia jest zespoloną funkcją częstości, której moduł przedstawia charakterystykę amplitudowo-częstościową, a argument jest kątem przesunięcia fazowego między siłą wymuszającą a odpowiedzią;

- funkcja koherencji będąca miarą spójności dwu procesów drganiowych $x(t)$ i $y(t)$ (Ibrahim i Mikulcik, 1977):

$$
\gamma_{x y}^{2}(f)=\frac{\left|G_{x y}(f)\right|^{2}}{G_{x x}(f) G_{y y}(f)}
$$

Niezależnie od charakteru transmitancji dróg przejścia funkcja koherencji przyjmuje zawsze wartość 1 , jeżeli tylko sygnały $x(t) i y(t)$ pochodzą $\mathrm{z}$ tego samego źródła. Dla większej liczby źródeł niż jedno funkcja koherencji będąca nieujemną jest zawsze mniejsza od jedności (z przedziału od 0 do 1). Funkcja koherencji jako miara spójności dwu sygnałów ma dobre własności diagnostyczne, gdyż pojawienie się sygnału nowego uszkodzenia narusza spójność poprzednich, przez co funkcja koherencji maleje (Żółtowski, Łukasiewicz i Kałaczyński, 2012).

Nowe narzędzia badań wypracowane $\mathrm{w}$ tej pracy dotyczą głównie oceny możliwości zastosowań 
zaproponowanych miar drganiowych, nowoczesnego przetwarzania drgań i statystycznego wnioskowania przyczynowo-skutkowego w badaniu wybranych materiałów budowlanych.

\section{MATERIA I METODY}

Badania przeprowadzono na wybranych losowo sześciu bloczkach betonowych na stanowiskach laboratoryjnych, celowo do tego przystosowanych i odpowiednio wyposażonych. Zapewnienie ograniczonej liczby stopni swobody zapewniono poprzez zawieszenie badanych bloczków na cienkiej żyłce. Czujniki odbioru sygnałów mocowano na wosk, a kierunki wymuszeń przyjęto jak na rysunku 3 (Żółtowski, 2007).

Do pomiarów przebiegów czasowych wymuszenia i odpowiedzi układu, a także do określenia funkcji $H(f), F R F$ i koherencji wykorzystano najnowocześ-

a

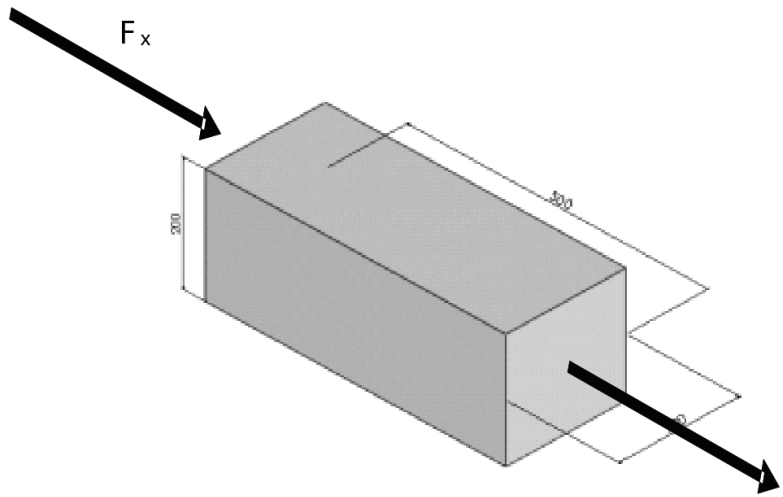

$\mathrm{ax}_{\mathrm{x}}$ niejszą aparaturę pomiarową firmy LMS pod nazwa LMS TEST.XPRESS. Oprogramowanie to umożliwia przeprowadzenie analizy rozpływu energii drganiowej w elementach i innych dowolnych konstrukcjach budowlanych.

Oprogramowanie LMS TestXpress 4A pozwala na rejestracje sygnału wymuszenia i odpowiedzi w postaci przebiegów czasowych oraz jest zdolne do wygenerowania funkcji wzajemnych i ich wartości liczbowych (pole pod krzywą) zastosowanych w badaniach tej pracy (Żółtowski, 2011b).

Interesującym przypadkiem prowadzonych badań tej pracy były wyniki uzyskane dla pękniętego bloczka betonowego, z wyraźną szczeliną w elemencie badanym, co pokazano na rysunku 4.

W badaniach na maszynie wytrzymałościowej INSTRON 8502 ustalono zakres granicznych obciążeń dla badanych bloczków betonowych do

Rys. 3. Mocowanie badanych bloczków i czujników piezoelektrycznych

Fig. 3. Mounting of tested blocks and piezoelectric sensors

Rys. 4. Prasa hydrauliczna INSTRON (a) i badania zniszczeniowe (b)

Fig. 4. INSTRON hydraulic press (a) and destruction tests (b)

a

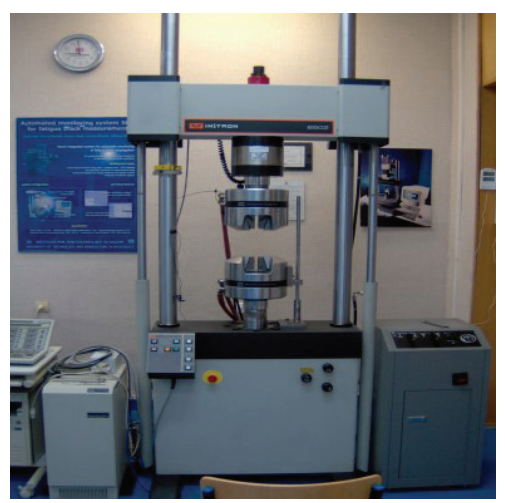

b

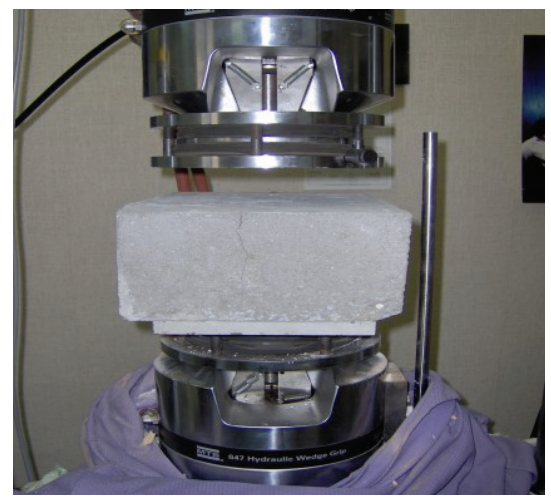


zniszczenia, co pozwoliło ustalić obciążenia testowe dla badań szczegółowych. Badania niszczące wybranych przeprowadzono na sześciu bloczkach betonowych i po uśrednieniu wyników zaproponowano wartości obciążeń do badań podstawowych.

\section{WYNIKI I DYSKUSJA}

Przebiegi czasowe siły wymuszenia (jej stałość zapewnia system APB-200) i odpowiadajace tym wymuszeniom przebiegi przyspieszenia drgań dla grupy badanych sześciu bloczków betonowych pokazano przykładowo w układzie współrzędnych: przyśpieszenie-czas na rysunku 5 dla elementów bez obciążenia destrukcyjnego. Podobne analizy zarejestrowano dla potrzeb dalszego przetwarzania dla siły wymuszającej drgania, a także dla wyróżnionych na maszynie wytrzymałościowej obciążeń.

Wartości liczbowe miar sygnałów drganiowych dla badanego bloczka betonowego przy różnych zalecanych w badaniach tej pracy poziomach obciążeń siłowych przedstawiono $\mathrm{w}$ tabeli.

$\mathrm{Na}$ kolejnych rysunkach przedstawione zostały przebiegi siły wymuszenia młotkiem modalnym i odpowiadające im amplitudy przyspieszeń drgań dla badanych elementów murowych przy obciążeniach materiałów badanych odpowiednio: $F 1, F 2, F 3$, określonych w tabeli. Warto zauważyć, że w czasie badań bloczki betonowe były obciążane siłami odpowiednio o wartościach: 50, 100, $150 \mathrm{kN}$.

Uwzględniając wszystkie prowadzone analizy wrażliwości, za pomocą różnych metod statystycznych zastosowanych $\mathrm{w}$ tej pracy wstępnie można zaproponować jako główne miary stanu destrukcji bloczka betonowego: $F R F_{r}, F R F_{u}, H(f)_{r}, H(f)_{u}, U_{R M S}$, coher, $\omega_{2}$.

$\mathrm{W}$ wyniku przeprowadzonych badań dla wskazanych obciążeń wzdłuż osi $Z$ otrzymano wyniki przedstawione na rysunku 6.

Na rysunku 6 przedstawiono przebiegi siły wymuszenia (a), odpowiadającej jej amplitudy przyśpieszenia drgań (b), widma drgań tych sygnałów (c, d) oraz przykładowe miary destrukcji: $F R F$, wartości częstości drgań własnych z diagramu stabilizacji z wyróżnieniem charakterystycznej częstości $\left(\omega_{2}\right)$, przebieg funkcji koherencji (coher) oraz wskaźnik zaniku drgań funkcji korelacji wzajemnej $(\delta)$. Wyraźnie widać różnice otrzymanych miar dla pękniętego bloczka w stosunku do nieuszkodzonego, co objawia się głównie pojawieniem się drugiej częstości drgań własnych na poziomie $150 \mathrm{~Hz}$ (rys. 6d), $F R F$ oraz $\omega_{2}$

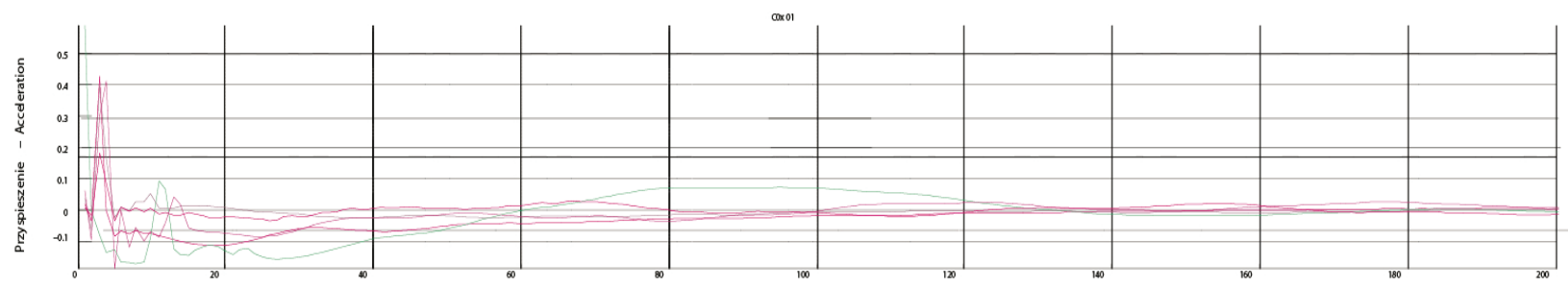

Czas - Time

Rys. 5. Amplitudy przyspieszenia drgań badanego bloczka dla różnych obciążeń F0x

Fig. 5. Amplitudes of acceleration of vibrations of the tested pulley for various loads F0x

Tabela. Dane pomiarowe wstępnie wybranych miar

Table. Measurement data of pre-selected measures

\begin{tabular}{lccccccccc}
\hline$F$ & $F R F_{r}$ & $F R F_{u}$ & $H(f)_{r}$ & $H(f)_{u}$ & coher & $\delta$ & $U_{R M S}$ & $\omega_{1}$ & $\omega_{2}$ \\
\hline 0 & 1824,87 & 40,32 & 20,80 & 1,57 & 179,48 & 0,916 & 0,011 & 4 & 40 \\
\hline 50 & 1115,24 & $-1502,55$ & 8,56 & 22,56 & 107,01 & 0,992 & 0,011 & 2 & 40 \\
\hline 100 & 326,82 & $-340,92$ & $-3,01$ & 24,57 & 92,48 & 0,969 & 0,011 & 2 & 30 \\
\hline 150 & $-1084,96$ & $-397,68$ & $-14,48$ & 21,46 & 88,45 & 0,959 & 0,011 & 2 & 50 \\
\hline
\end{tabular}


a

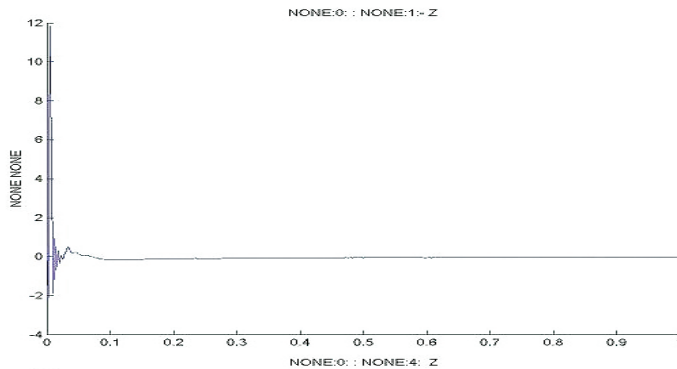

$\mathrm{b}$

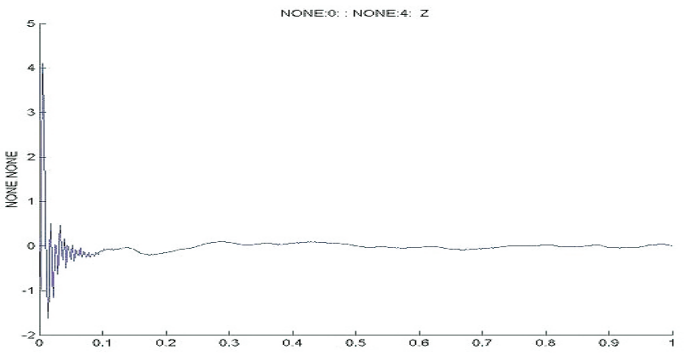

$F R F$

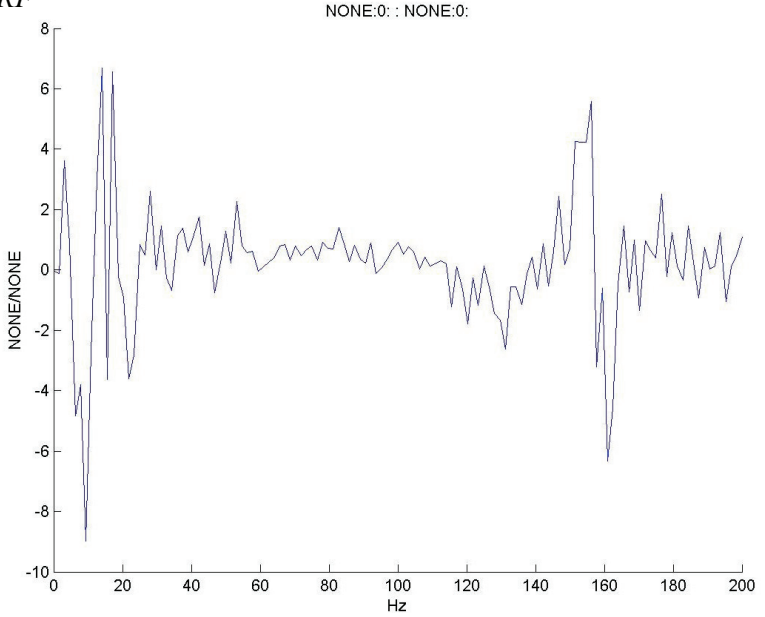

coher

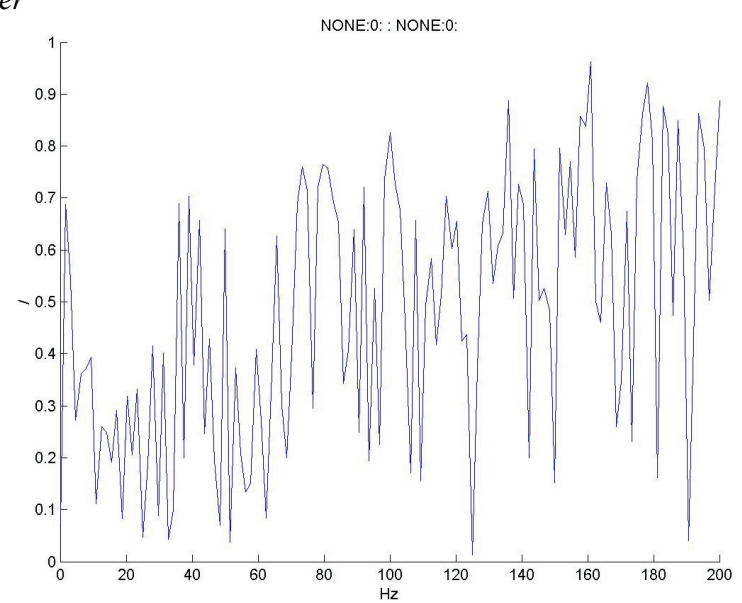

d

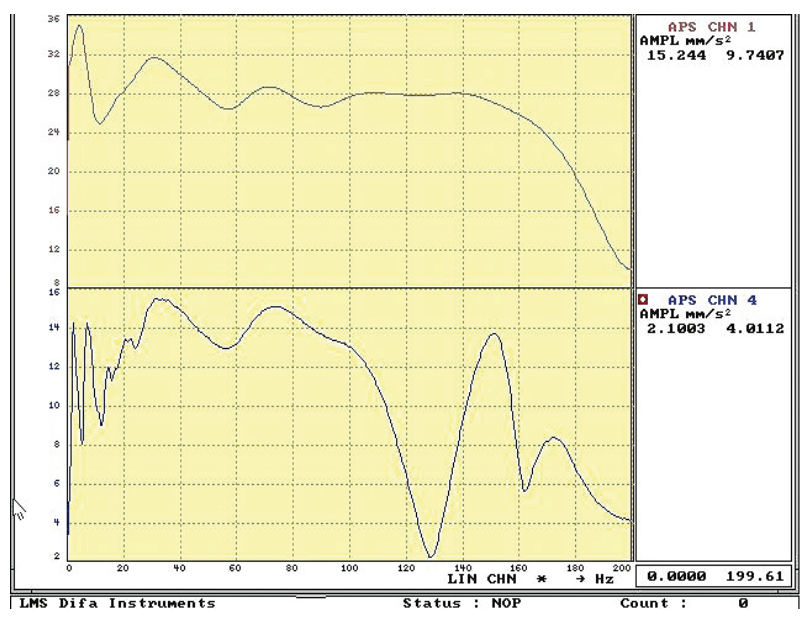

$\omega_{2}$

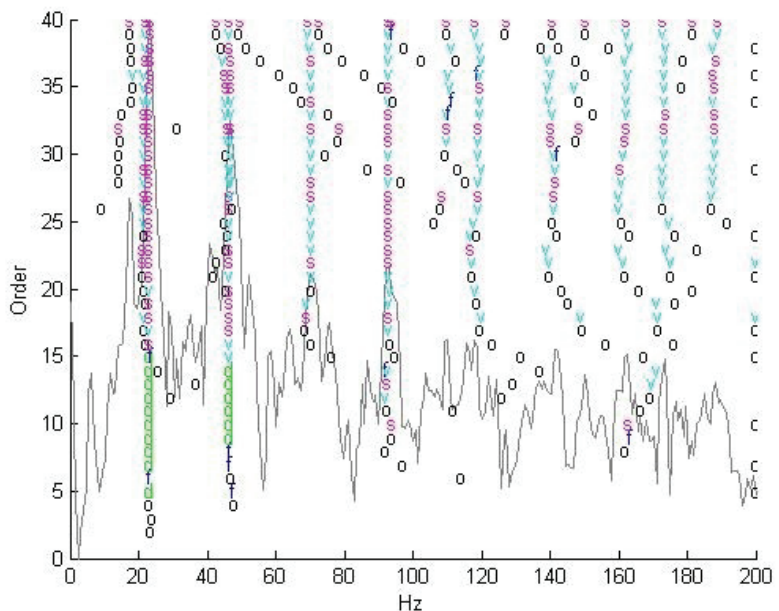

$\delta$

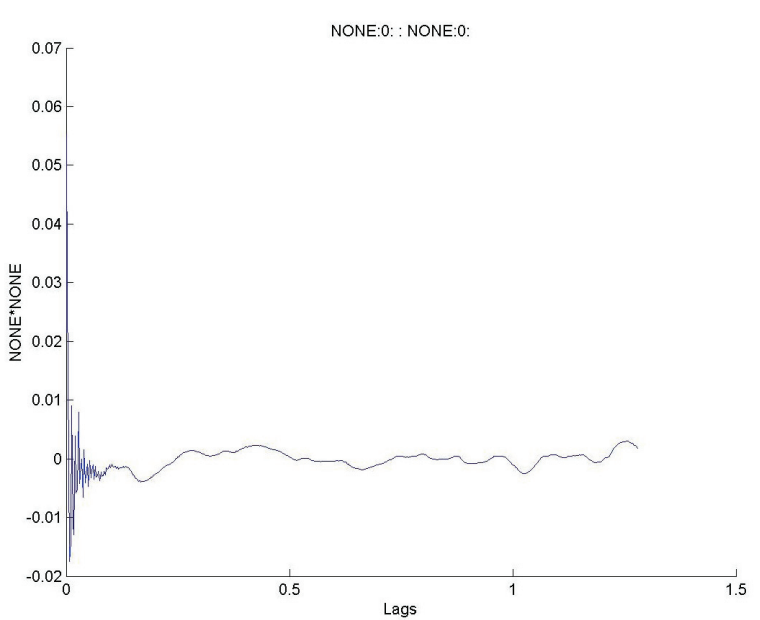

Rys. 6. Wyniki badań stanowiskowych w osi X (bez obciążenia) - bloczek pęknięty (opis w tekście)

Fig. 6. Results of bench tests in the $\mathrm{X}$ axis (without load) - pulley broken (description in the text) 
Wszystkie przebiegi funkcyjne zostały dalej opracowane (dyskretyzowane) liczbowo i wykorzystane podczas wnioskowania jakościowego przy zastosowaniu zaproponowanych wcześniej metod statystycznych (Shih, Tsuei, Allemang i Brown, 1988).

Zróżnicowanie drganiowych miar stanu dla zdatnego i uszkodzonego bloczka w badaniach tej pracy przedstawiono na rysunku zbiorczym (rys. 7) w postaci diagramów stabilizacyjnych i wartości pól pod krzywymi funkcji koherencji (coher) i FRF.

Dalsza procedura postępowania zgodna z proponowaną w pracach autora metodologią badań rozpływu energii drganiowej miała na celu wyznaczenie dobrych miar stanu destrukcji badanych bloczków
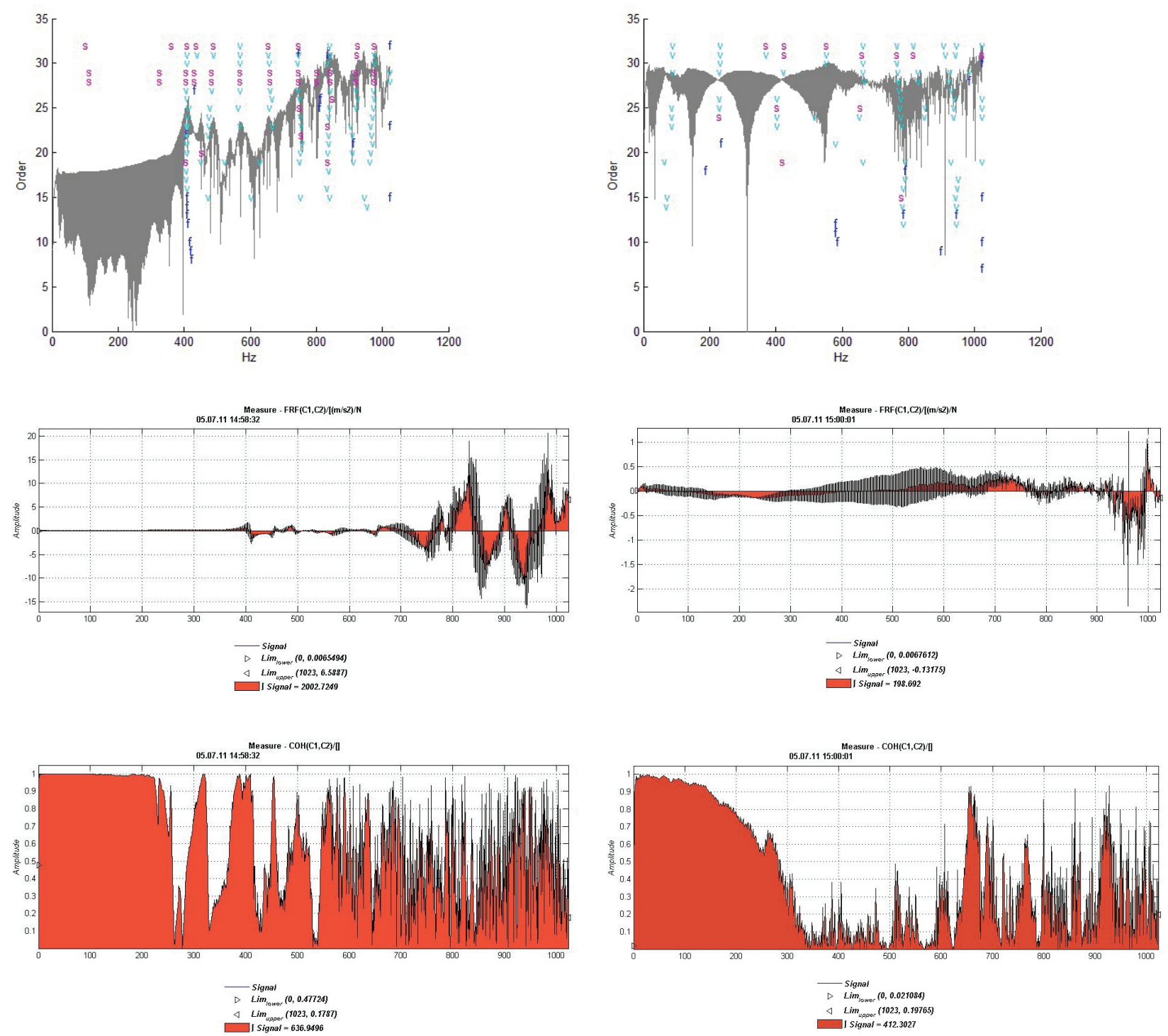

Rys. 7. Diagramy stabilizacyjne, FRF i funkcji koherencji (coher) dla zdatnego (a) i uszkodzonego bloczka betonowego (b)

Fig. 7. Stabilization diagrams, $F R F$ and coherence function (coher) for a fit (a) and damaged concrete block (b) 
betonowych oraz ustalenie relacji przyczynowoskutkowych między stanem destrukcji bloczka a jego miarami. Uzyskano to poprzez badanie relacji funkcyjnej oddzielnie dla każdej zmiennej, czyli dla każdej miary indywidualnie charakteryzującej stan destrukcji oraz podczas badania funkcji wielu zmiennych, dla wszystkich miar jednocześnie. Badania tych relacji matematycznych przeprowadzono przy wykorzystaniu regresji prostej i regresji wielokrotnej, a odpowiednie równania pokazano bezpośrednio na rysunkach krzywych regresji (Żółtowski, Żółtowski i Castaneda, 2013).

Dla wyróżnionych miar stanu degradacji wyznaczono regresyjne modele czastkowe przykładowo przedstawione na rysunku 8 . Do aproksymacji postaci funkcji między stanem destrukcji a miarami tego stanu przyjęto preferowane $\mathrm{w}$ statystyce wielomiany algebraiczne, ze szczególnie zalecanym wielomianem drugiego stopnia. Uzyskane relacje wskazują, na ile zmiany obciążenia badanych elementów murowych wpływają na zmiany wartości, wybranych w proce- durze badania (indywidualnej lub wielorakiej), miar sygnału drganiowego.

Miary błędów aproksymacji badanych funkcji określano współczynnikiem korelacji wielowymiarowej $\left(R^{2}\right)$ nazywanym też współczynnikiem determinacji, przyjmującym wartości z przedziału $[0,1]$. Jego wartości podano na rysunkach regresji, przy czym im większa jest jego wartość, tym lepsza korelacja-lepsze dopasowanie krzywej regresji do wyników pomiarów.

Spodziewanym efektem redukcji danych dla przyjętej jakości klasyfikacji stanu jest uproszczenie struktury zbioru danych, uproszczenie algorytmu klasyfikacji, skrócenie czasu obliczeń, zwiększenie szybkości pracy systemu, zmniejszenie kosztów realizacji technicznej.

Ostatecznie miary degradacji stanu dla bloczka betonowego to: $F R F_{r}, H(f)_{r}$, coher, stosowane zgodnie $\mathrm{z}$ modelem przedstawionym na rysunku 9 .

Opracowany model do badań degradacji bloczków betonowych ujmujący miary dobrze różnicujące stan destrukcji jest podstawa do budowy metody badania użytecznej w produkcji przemysłowej.
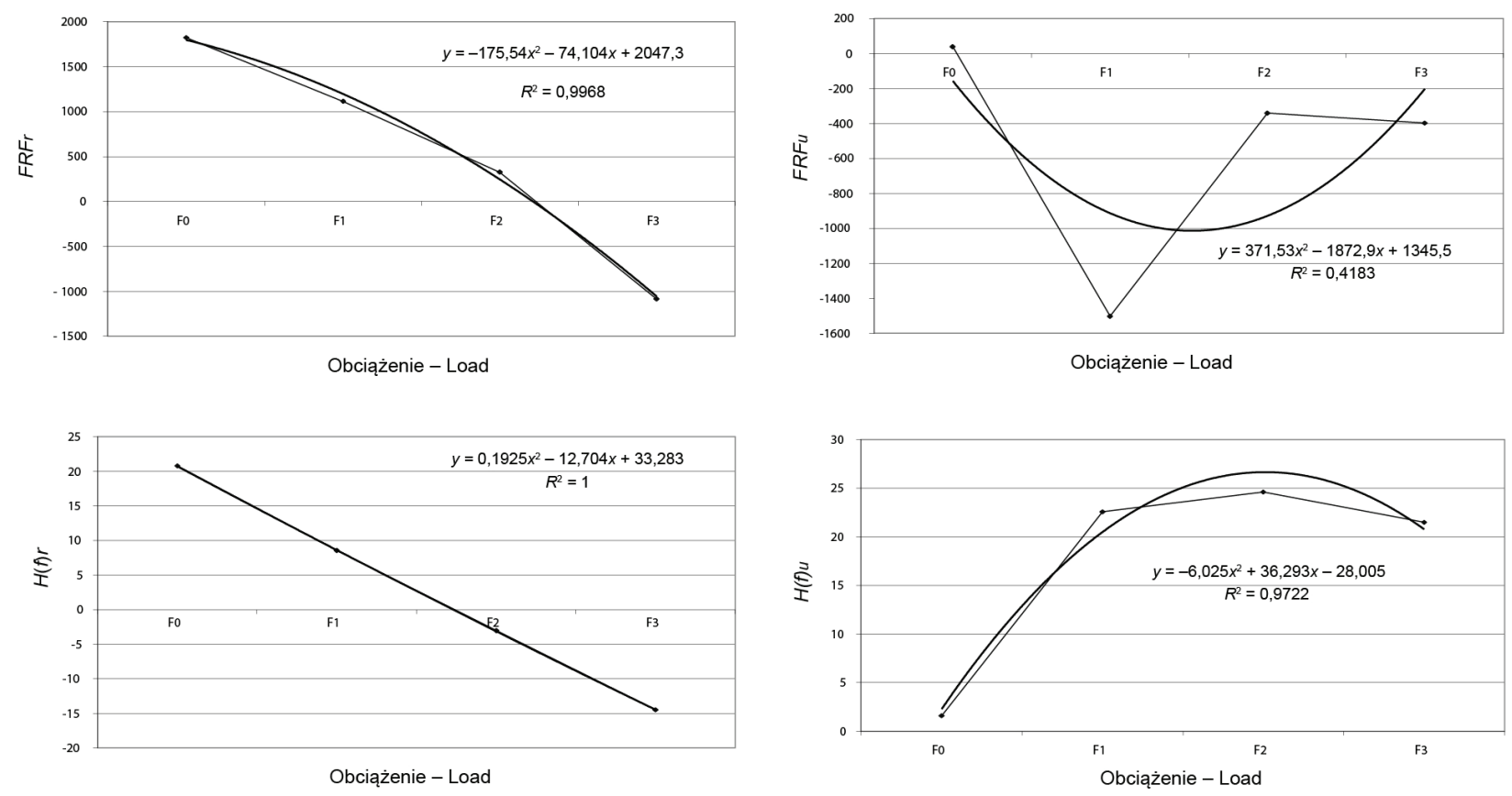

Rys. 8. Modele cząstkowe dla wskazanych miar drganiowych

Fig. 8. Partial models for the indicated vibration measures 


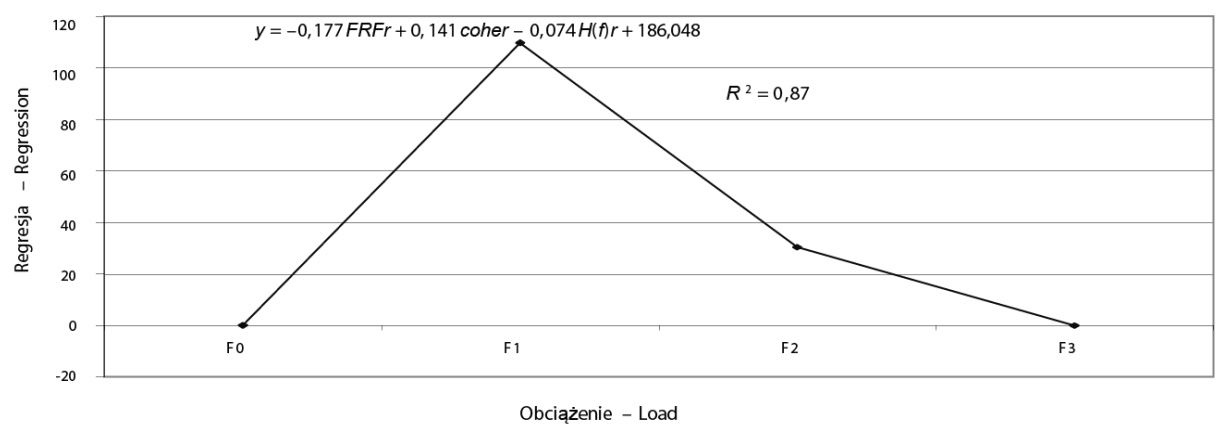

Rys. 9. Wynikowy model przyczynowo-skutkowy dla badanych bloczków betonowych

Fig. 9. The resulting cause-effect model for the tested concrete blocks

\section{PODSUMOWANIE}

Pomiary drgań wraz z ich interpretacją fizyczną są podstawą pozyskiwanej informacji $\mathrm{w}$ badaniu destrukcji wybranych konstrukcji budowlanych lub ich elementów murowych.

Przeprowadzona w tym opracowaniu egzemplifikacja metody na grupie bloczków betonowych potwierdziła zgodność i skuteczność proponowanej metodyki opracowanej dla badań degradacji materiałów i konstrukcji w budownictwie. Pozytywnie zweryfikowano założenia wypracowanej metodyki badań i potwierdzono skuteczność złożonych miar drganiowych w zastosowaniu do oceny stanu degradacji materiałów murowych, co dobrze rokuje dla potrzeb badań rzeczywistych na obiektach wieloletnich.

Rozważania tego opracowania potwierdzają przydatność zaproponowanych algorytmów i programów wspomagających realizację metodyki badawczej, czyli: pozyskiwanie i przetwarzanie informacji, redukcję nadmiaru informacji, wnioskowanie statystyczne oraz prezentację wyników badania.

Pęknięcie bloczka można lokalizować za pomocą funkcji koherencji, mającej już w zapisie matematycznym wskazanie do oceny energii między punktami, oraz miar wzajemnych: transmitancji i jej inwersji $(F R F)$.

\section{Indywidualny wkład autorów}

Koncepcja pracy: M.Ż. i N.D.; metodyka: M.Ż.; oprogramowanie: M.Ż.; walidacja danych: M.Ż. i N.D.; analiza formalna: N.D.; badania: M.Ż.; zasoby: M.Ż.; kompilacja i opracowanie danych: M.Ż.; sporządzenie wstępnej wersji artykułu: N.D.; redakcja i korekta artykułu: M.Ż.; wizualizacja i oprawa graficzna: M.Ż.; nadzór: N.D.

Wszyscy autorzy zapoznali się z przeznaczoną do publikacji wersją manuskryptu.

\section{PIŚMIENNICTWO}

Batel, M. (2002). Operational Modal Analysis another way of doing modal testing. IEEE Transactions on Industry Applications, 36 (8), 22-27.

Bischoff, M., Wall, W., Bletzinger, K-U. i Ramm, E. (2004). Models and Finite Elements for Thin-walled Structures. Encyclopedia of Computational Mechanics. New Jersey: John Wiley \& Sons.

Bishop, R. E. D. i Johnson, D. (1980). The Mechanics of Vibration. Cambridge: Cambridge University Press.

Brandt, S. (1999). Analiza danych. Warszawa: Wydawnictwo Naukowe PWN.

Brunarski, L. (1996). Nieniszczace badania betonu. Warszawa: Arkady.

Ibrahim, S. R. i Mikulcik, E. C. (1977). A method for the direct identification of vibration parameters from the free response. Sound and Vibration Bulletin, 4 (47), 183-198.

Natke, H. G. i Cempel, C. (1997). Model-Aided Diagnosis of Mechanical Systems. Berlin-Heidelberg: Springer.

Peeters, B. i Ventura, C. (2003). Comparative study of modal analysis techniques for bridge dynamic characteristics. Mechanical Systems and Signal Processing, 17 (5), 965-988.

Pickrel, C. R. (2002). Airplane Ground Vibration Testing - Nominal Modal Model Correlation. Sound and Vibration, 36 (11), 18-23. 
Richardson, M. H. (1997). Is it a mode shape or an operating deflection shape? Sound and Vibration, 31 (1), 54-61.

Richardson, M. H. i Formenti, D. L. (1982). Parameter Estimation from Frequency Response Measurements Using Rational Fraction Polynomials. W P.B. Juhl (ed.), Proceedings of the 1st International Modal Analysis Conference \& Exhibit, Orlando, 08-10.11.1982 (strony 167-181). New York: Union College.

Shih, C. Y., Tsuei, Y. G., Allemang, R. J. i Brown, D. L. (1988). Complex mode indication function and its applications to spatial domain parameter estimation. Mechanical Systems and Signal Processing, 2 (4), 367-377.

Uhl, T. (1997). Komputerowo wspomagana identyfikacja modeli konstrukcji mechanicznych. Warszawa: WNT.

Vold, H., Kundrat, J., Rocklin, G. T. i Russell, R. (2010). A Multi-Input Modal Estimation Algorithm for MiniComputers. SAE Technical Paper 1.

Żółtowski, B., Łukasiewicz, M. i Kałaczyński, T. (2012). The investigations aid in exploitation. Diagnostyka, 2 (62), 65-69.
Żółtowski, M. (2005). Pomiary właściwości akustycznych materiałów. Materiały XII Międzynarodowej Konferencji „Diagnostyka Maszyn Roboczych i Pojazdów”, Bydgoszcz, 23-25.06.2005. Diagnostyka, 33, 168-172.

Żółtowski, M. (2007). Selection of information on identification of the state of machine. Acta Academia, 310, 55-70.

Żółtowski, M. (2011a). Komputerowe wspomaganie zarzqdzania systemem eksploatacji $w$ przedsiębiorstwie produkcyjnym. Komputerowo zintegrowane zarzadzanie. Vol. 2. Opole: Oficyna Wydawnicza PTZP.

Żółtowski, M. (2011b). Analiza modalna $w$ badaniach materiatów budowlanych. Radom: ITE-PIB.

Żółtowski, M. (2014). Investigations of harbour brick structures by using operational modal analysis. Polish Maritime Research, 21 (1), 42-53.

Żółtowski, M., Żółtowski, B. i Castaneda, L. (2013). Study of the state a Francis turbine. Polish Maritime Research, 20 (2), 41-47.

\section{MODAL TESTS OF CONCRETE BLOCK CRACKS}

\section{ABSTRACT}

The presented study indicated the possibility of using complex estimates of the vibrational energy flow used in testing the quality of concrete blocks, as part of a dedicated research methodology and detailed methodologies. Theoretical analysis and practical verification of the sensitivity testing of informational measures of complex vibration processes indicate the wide possibilities of their applications. Recognising the need to improve the methods of testing machines and building structures for the purpose of assessing their degradation status - this paper presents the important results of the research procedure in the field of verification of the effectiveness of the proposed mutual measures in concrete block test bench tests.

Key words: structure loads, state degradation, vibrations, vibration estimators, statistical analysis 